\title{
Basset Hound
}

National Cancer Institute

\section{Source}

National Cancer Institute. Basset Hound. NCI Thesaurus. Code C53896.

The Basset Hound has a large head, with a rounded skull. It has loose-fitted skin that falls in folds on the head and very long, velvety ears. The coat is short. The body shape is longer than it is tall with very short legs. Height: 11-15 inches $(28-38 \mathrm{~cm})$ Weight: 45-65 pounds (20-29 kg.) 